\title{
Hubungan Kompetensi Guru dan Peran Orang Tua Terhadap Terhadap Hasil Belajar Siswa di MIN Se-Kota Palembang
}

\author{
Aquami \\ Prodi PGMI Fakultas Ilmu Tarbiyah dan Keguruan \\ Universitas Islam Negeri Raden Fatah Palembang \\ E-mail: aqumi_uin@radenfatah.ac.id \\ Tutut Handayani \\ Prodi PGMI Fakultas Ilmu Tarbiyah dan Keguruan \\ Universitas Islam Negeri Raden Fatah Palembang \\ E-mail: tututhandayani uin@ radenfatah.ac.id \\ Ibrahim \\ Prodi PGMI Fakultas Ilmu Tarbiyah dan Keguruan \\ Universitas Islam Negeri Raden Fatah Palembang \\ e-mail: ibrahimuin@ @radenfatah.ac.id
}

Abstrak:Guru adalah pendidik profesional dengan tugas utamanya mendidik, mengajar, membimbing, mengarahkan, melatih, menilai dan mengevaluasi peserta didik dalam jalur formal. Guru dalam menjalankan fungsinya diantaranya berkewajiban untuk menciptakan suasana pendidikan yang bermakna, menyenangkan, kreatif, dinamis, dialogis, dan memberikan motivasi kepada siswa dalam membangun gagasan, prakarsa, dan tanggung jawab siswa untuk belajar. Begitu juga peran orang tua. Orang tua tidak hanya bertugas memberikan secara financial dan hanya berkewajiban menyekolahkan tetapi juga ada tanggungjawab untuk membimbing, mengarahkan dan memfasilitasi anaknya untuk belajar dan menciptakan suasana yang kondusif untuk belajar dirumah. Jenis penelitian ini adalah penelitian kuantitatif, adapun metode dalam penelitian ini menggunakan metode survey. Dalam penelitian ini peneliti akan menggunakan sampel pada siswa di MIN se-Kota Palembang. Variabel dalam penelitian ini adalah: Kompetensi Guru (X1), Peran Orang Tua (X2), Hasil Belajar (Y). Teknik pengumpulan data akan dilakukan dengan wawancara, angket, observasi dan gabungan dari ketiganya. Selanjutnya untuk analisis data peneliti menggunakan uji korelasi ganda (multiple Correlate). Kesimpulan dari penelitian ini yaitu berdasarkan data yang didapatkan dari hasil penelitian terlihat bahwa rata-rata kompetensi guru di MIN 1 adalah 164.58 yang tergolong dalam kategori baik, kemudian rata-rata kompetensi guru di MIN 2 adalah 169.7 yang tergolong dalam kategori sangat baik. Selanjutnya berdasarkan data yang didapatkan dari hasil penelitian terlihat bahwa rata-rata peran orang tua di MIN 1 adalah 79.34 yang tergolong kategori baik, kemudian rata-rata peran orang tua di MIN 2 adalah 81.9 yang tergolong dalam kategori baik. Kemudian hasil perhitung didapat $F_{\text {hitung }}=$ 3.933039 dan $F_{\text {tabel }}=3.443357$, maka $F_{\text {hitung }}>F_{\text {tabel }}$ yaitu $3.933039>3.443357$ dengan demikian maka, kesimpulannya yaitu terdapat hubungan yang signifikan antara kompetensi guru dan peran orang tua terhadap hasil belajar siswa MIN 1 Palembang, kemudian Hasil perhitung didapat $F_{\text {hitung }}=3.933039$ dan $F_{\text {tabel }}=3.443357$, maka $F_{\text {hitung }}>F_{\text {tabal }}$ yaitu $3.933039>3.443357$ dengan demikian maka, kesimpulannya yaitu terdapat hubungan yang signifikan antara kompetensi guru dan peran orang tua terhadap hasil belajar siswa MIN 2 Palembang 
Kata Kunci: kompetensi guru, peran orang tua, hasil belajar.

\section{A. Pendahuluan}

Pembelajaran merupakan suatu proses yang dilakukan secara sadar pada setiap individu atau kelompok untuk merubah sikap dari tidak tahu menjadi tahu sepanjang hidupnya. Sedangkan proses belajar mengajar merupakan kegiatan pokok sekolah yang di dalamnya terjadi proses siswa belajar dan guru mengajar dalam konteks interaktif dan terjadi interaksi edukatif antara guru dan siswa, sehingga terdapat perubahan dalam diri siswa baik perubahan pada tingkat pengetahuan, pemahaman dan keterampilan ataupun sikap. Melalui proses mengajar tersebut akan dicapai tujuan pendidikan tidak hanya dalam hal membentuk perubahan tingkah laku dalam diri siswa, akan tetapi juga meningkatkan pengetahuan yang ada dalam diri siswa.

Dalam pendidikan saat ini, guru seringkali mendapatkan kesulitan dalam pembelajaran. Misalnya: siswa merasa bosan ketika pembelajaran berlangsung karena tidak ada yang membuat semangat dalam pembelajaran tersebut. Hal ini menyebabkan kurang aktifnya siswa dalam kegiatan pembelajaran, apalagi pada pelajaran yang dianggapnya sulit.

Sementara itu orang tua juga memiliki tanggung jawab yang besar terhadap pendidikan anaknya, orang tua tidak dapat menyerahkan sepenuhnya tanggung jawab pendidikan kepada sekolah, Sekolah hanyalah penunjang pendidikan seorang anak, orangtua lah yang mempunyai peran utama dalam mendidik anaknya, maka peran sekolah bukan hanya untuk anak tapi lebih utamanya untuk orangtuanya. Dari sinilah parenting dianggap perlu bagi sekolah terhadap orangtua guna mewujudkan sinergi antara orangtua, anak dan sekolah. Sehingga diharapkan dapat meningkatkan hasil belajar siswa.

Dalam setiap mengikuti proses pembelajaran di sekolah sudah pasti setiap peserta didik mengharapkan mendapatkan hasil belajar yang baik, sebab hasil belajar yang baik dapat membantu peserta didik dalam mencapai tujuannya. Hasil belajar yang baik hanya dicapai melalui proses belajar yang baik pula. Jika proses belajar tidak optimal sangat sulit diharapkan terjadinya hasil belajar yang baik.

Peran guru yang berkompetensi dan bimbingan orang tua siswa secara maksimal diharapkan dapat meningkatkan motivasi belajar siswa, yang selanjutnya juga diharapkan berdampak pada meningkatnya hasil belajar siswa. Karena berdasarkan observasi awal, anak yang dididik oleh guru yang berkompetensi dan memiliki orang tua yang bertanggung jawab terhadap pendidikan mereka memiliki motivasi belajar yang tinggi dan hasil belajar yang maksimal.

Oleh karena itu, artikel ini mencoba membuktikan teori-teori tersebut dengan mengangkat tema penelitian yakni hubungan kompetensi guru dan peran orang tua terhadap terhadap hasil belajar siswa di MIN Se-Kota Palembang, dengan rumusan masalah bagaimana kompetensi guru, peran orang tua dalam mempengaruhi hasil belajar siswa dan apakah terdapat hubungan yang signifikan antara kompetensi guru dan peran orang tua terhadap Hasil Belajar Siswa di MIN Se-Kota Palembang.

\section{B. Kajian Teori}

\section{Kompetensi Guru}

Guru adalah pendidik profesional dengan tugas utama mendidik, mengajar, membimbing, mengarahkan, melatih, menilai, dan mengevaluasi peserta didik pada pendidikan anak usia dini jalur pendidikan formal, pendidikan dasar, dan menengah 
(Undang-Undang No.14 Tahun 2005). Guru merupakan seseorang yang mempunyai tugas mulia untuk mendorong, membimbing dan memberi fasilitas belajar bagi siswa untuk mencapai tujuan. Guru mempunyai tanggung jawab untuk melihat segala sesuatu yang terjadi dalam kelas untuk membantu proses perkembangan siswa. Penyampaian materi pelajaran hanyalah merupakan salah satu dari berbagai kegiatan dalam belajar sebagai suatu proses yang dinamis dalam segala fase dan proses perkembangan siswa.

Kompetensi guru dapat dimaknai sebagai kebulatan pengetahuan, keterampilan dan sikap yang berwujud tindakan cerdas dan penuh tanggung jawab dalam melaksanakan tugas sebagai agen pembelajaran. Guru merupakan salah satu faktor yang sangat penting dalam meningkatkan kualitas pendidikan. Di tangan guru yang cekatan; fasilitas dan sarana yang kurang memadai dapat diatasi, tetapi sebaliknya ditangan guru yang kurang cakap: sarana dan fasilitas yang canggih tidak banyak memberi manfaat.

Berangkat dari masalah di atas, maka langkah pertama yang dilakukan untuk memperbaiki kualitas pendidikan adalah dengan memperbaiki kualitas tenaga pendidiknya terlebih dahulu. Oleh karena itu, salah satu langkah untuk menjadi guru profesional yang nantinya akan meningkatkan kualitas pendidikan adalah guru harus memiliki kompetensi.

Kompetensi guru terkait dengan kewenangan melaksanakan tugasnya, dalam hal ini dalam menggunakan bidang studi sebagai bahan pembelajaran yang berperan sebagai alat pendidikan, dan kompetensi pedagogis yang berkaitan dengan fungsi guru dalam memperhatikan perilaku peserta didik belajar.

Kompetensi guru juga merupakan orang yang profesinya atau pekerjaannya mengajar dan memiliki kemampuan dan kewenangan dalam melaksanakan profesi keguruannya. Selain itu, kompetensi guru merupakan kemampuan atau kesanggupan guru dalam melaksanakan tugasnya, melaksanakan proses belajar mengajar, kemampuan atau kesanggupan untuk benar-benar memiliki bekal pengetahuan dan keterampilannya sesuai dengan sebaik-sebaiknya (Iwah Wahyudi, 2012: 102).

Makna penting kompetensi dalam dunia pendidikan didasarkan atas keseimbangan rasional, bahwasannya proses pembelajaran merupakan proses yang rumit dan kompleks. Ada beragam aspek yang saling berkaitan dan memengaruhi berhasil atau gagalnya kegiatan pembelajaran (Ngainun Naim, 2013: 56-57). Banyak guru yang telah bertahun-tahun mengajar, tetapi sebenarnya kegiatan yang dilakukan tidak banyak memberikn aspek perubahan positif dalam kehidupan siswanya. Sebaliknya, ada juga guru yang relatif baru namun telah memberikan kontribusi konkrit kearah kemajuan dan perubahan positif pada diri siswa.

Dari pengertian di atas dapat disimpulkan bahwa kompetensi guru adalah hasil dari penggabungan dari kemampuan-kemampuan yang banyak jenisnya, dapat berupa seperangkat pengetahuan, keterampilan, dan perilaku yang harus dimiliki, dihayati, dan dikuasai oleh guru dalam menjalankan tugas keprofesionalannya. Standar kompetensi guru dipilah ke dalam tiga komponen yang saling berkaitan, yaitu pengelolaan pembelajaran, pengembangan profesi, dan penguasaan akademik.

\section{a. Kompetensi Pedagogik}

Kompetensi pedagogik meliputi pemahaman guru terhadap peserta didik, perancangan dan pelaksanaan pembelajaran, evaluasi hasil belajar, dan pengembangan peserta didik untuk mengaktualisasikan berbagai potensi yang dimilikinya.

Paedagogia yang berarti pergaulan dengan anak, Pedagogik yang merupakan praktek pendidikan anak dan kemudian muncullah istilah "Pedagogik 
yang berarti ilmu mendidik anak" (Alisuf Sabri, 1998: 35-40). Kompetensi pedagogik sesuia dengan UU RI Guru dan Dosen Nomor 14 tahun 2005 dan PP Nomor 19/2005 adalah merupakan kemampuan yang berkenaan dengan pemahaman peserta didik dan mengelola pembelajaran yang mendidik dan dialogis (Undangundang No.14 Tahun 2005). Tim Direktorat Profesi Pendidikan Ditjen Peningkatan Mutu Pendidikan dan Tenaga Kependidikan (2006) telah merumuskan secara substantif kompetensi pedagogik yang mencakup kemampuan terhadap peserta didik. Pemahaman wawasan atau landasan kependidikan pengembangan peserta didik untuk mengaktualisasikan berbagai potensi yang dimilikinya.

Kompetensi pedagogik pada dasarnya adalah kemampuan guru dalam mengelola pembelajaran peserta didik. Kompetensi yang merupakan kompetensi khas, yang membedakan guru dengan profesi lainnya ini terdiri dari 7 aspek kemampuan, yaitu:

1) Mengenal karakteristik anak didik

2) Menguasai teori belajar dan prinsip-prinsip pembelajaran

3) Mampu mengembangkan kurikulum

4) Kegiatan pembelajaran yang mendidik

5) Memahami dan mengembangkan potensi peserta didik

6) Komunikasi dengan peserta didik

7) Penilaian dan evaluasi pembelajaran

\section{b. Kompetensi Kepribadian}

Pribadi guru memiliki andil yang sangat besar terhadap keberhasilan pendidikan, khususnya dalam kegiatan pembelajaran. Pribadi guru juga sangat berperan dalam membentuk pribadi peserta didik, termasuk mencontoh pribadi gurunya dalam membentuk pribadinya. Sangat dibutuhkan oleh peserta didik dalam proses pembentukan pribadinya. Kompetensi kepribadian memiliki peran dan fungsi yang sangat penting dalam membentuk kepribadian anak, guna menyiapkan dan mengembangkan sumber daya manusia serta mensejahterakan masyarakat, kemajuan negara, dan bangsa pada umumnya. Kepribadian pada prinsipnya adalah susunan atau kesatuan antara aspek prilaku mental (pikiran perasaan dan sebagainya) dengan aspek behavioral (perbuatannya) aspek-aspek ini berkaitan secara fungsional dalam diri seorang individu, sehingga membuatnya bertingkah laku secara khas dan tetap (Sumiati \& Asra, 2007: 23).

Kompetensi kepribadian adalah kemampuan personal yang mencerminkan kepribadian yang mantap, stabil, dewasa, arif, dan berwibawa dan menjadi teladan bagi peserta didik serta berakhlak mulia (Mulyasa, 2005: 72). Kompetensi kepribadian merupakan kemampuan personal yang mencerminkan kepribadian yang mantap, stabil, dewasa, arif, dan berwibawa, menjadi teladan bagi peserta didik, dan berakhlak mulia.

\section{c. Kompetensi Sosial}

Kompetensi sosial yaitu kemampuan guru untuk berkomunikasi dan bergaul secara efektif dengan peserta didik, sesama pendidik, tenaga pendidikan, orang tua/wali peserta didik dan masyarakat sekitar (Usman, 2011: 32). Kompetensi sosial juga merupakan kemampuan guru untuk berkomunikasi dan bergaul secara efektif dengan peserta didik, sesama pendidik, tenaga kependidikan, orang tua/wali peserta didik, dan masyarakat sekitar. 
Kompetensi sosial bisa dilihat apakah seorang guru bisa bermasyarakat dan bekerja sama dengan peserta didik serta guru-guru lainnya. Kompetensi sosial yang harus dikuasai guru meliputi:

1) Berkomunikasi lisan dan tulisan

2) Menggunakan teknologi komunikasi dan informasi secara fungsional

3) Bergaul secara efektif dengan peserta didik, sesama pendidik, tenaga kependidikan, orang tua/wali peserta didik

4) Bergaul secara santun dengan masyarakat sekitar

5) Bertindak sesuai dengan norma agama, hukum, sosial, dan kebudayaan nasional Indonesia

6) Menunjukkan pribadi yang dewasa dan teladan

7) Etos kerja, tanggung jawab yang tinggi, rasa bangga menjadi guru

\section{d. Kompetensi Profesional}

Kompetensi profesional berasal dari dua kata yaitu kompetensi dan profesional. Pengertian dasar kompetensi (competency) adalah kemampuan atau kecakapan (Muhibin Syah, 2000: 229). Dalam Kamus Besar Bahasa Indonesia kompetensi berarti kewenangan/kekuasaan untuk menentukan (memutuskan sesuatu) (Tim Penyusun Kamus Pusat Bahasa, 2002: 584).

Keputusan Menteri Pendidikan Nasional No. 045/4/2002 menyebutkan kompetensi sebagai seperangkat tindakan cerdas dan penuh tanggungjawab dalam melaksanakan tugas-tugas sesuai dengan pekerjaan tertentu (Keputusan Menteri Pendidikan Nasional No. 045/4/2002). Sedangkan profesional menunjuk pada dua hal, pertama orang yang menyandang suatu profesi, kedua penampilan seseorang dalam melakukan pekerjaan yang sesuai dengan profesinya (Wibowo, 2001: 2).

Kompetensi profesional dalam Sudarman menjelaskan bahwa kompetensi profesional terdiri dari dua subkompetensi yang pertama, subkompetensi menguasai substansi keilmuan yang terkait dengan bidang studi (memahami materi ajar yang ada dalam kurikulum sekolah, memahami struktur, konsep dan metode keilmuan yang menaungi atau koheren dengan materi ajar, memahami konsep antar mata pelajaran, dan menerapkan konsep-konsep keilmuan dalam kehidupan sehari-hari). Yang kedua menguasai struktur dan metode keilmuan (menguasai langkah-langkah penelitian dan kajian kritis untuk memperdalam pengetahuan atau materi bidang studi (Danim, 2010: 33).

Menurut Soedijarto dalam Kunandar kemampuan profesional guru meliputi : (1) merancang dan merencanakan program pembelajaran, (2) mengembangkan program pembelajaran, (3) mengelola pelaksanaan program pembelajaran, (4) menilai proses dan hasil pembelajaran, (5) mendiagnosis faktor yang mempengaruhi keberhasilan proses pembelajaran (Kunandar, 2011: 57).

Jadi dari berbagai pengertian di atas maka yang dimaksud dengan kompetensi profesional guru pendidikan agama Islam ialah kemampuan dan kewenangan guru dalam menjalankan profesi keguruannya, artinya guru yang piawai dalam melaksanakan profesinya dapat disebut sebagai guru yang kompeten dan profesional. Kompetensi profesional merupakan pekerjaan yang hanya dapat di lakukan oleh seorang yang mempunyai kualifikasi akademik, kompetensi dan sertifikat pendidik sesuai dengan persyaratan untuk setiap jenis dan jenjang pendidikan tertentu (Sholeh, 2006: 162). 


\section{Peran Orang Tua}

Filosofi keterlibatan orang tua murid dalam pembelajaran, tidak lepas dari besarnya ketergantungan anak-anak terhadap orang tuariya, kepribadian murid atau pendidikan kepribadian sekarang ini terpecah. Pada satu sisi, pendidikan itu berlangsung di rumah pada sisi lainnya di sekolah tidak ada kesatuan konsep.

Ada beberapa cara dalam meningkatkan peran orang tua terhadap pendidikan anak-anak mereka, diantaranya:

Pertama, dengan mengontrol waktu belajar dan cara belajar anak. Anak-anak diajarkan untuk belajar secara rutin, tidak hanya belajar saat mendapat pekerjaan rumah dari sekolah atau akan menghadapi ulangan. Setiap hari anak-anak diajarkan untuk mengulang pelajaran yang diberikan oleh guru pada hari itu. Dan diberikan pengertian kapan anak-anak mempunyai waktu untuk bermain.

Kedua, memantau perkembangan kemampuan akademik anak. Orang tua diminta untuk memeriksa nilai-nilai ulangan dan tugas anak mereka.

Ketiga, memantau perkembangan kepribadian yang mencakup sikap, moral dan tingkah laku anak-anak. Hal ini dapat dilakukan orang tua dengan berkomunikasi dengan wali kelas untuk mengetahui perkembangan anak di sekolah.

Keempat, memantau efektifitas jam belajar di sekolah. Orang tua dapat menanyakan aktifitas yang dilakukan anak mereka selama berada di sekolah. Dan tugastugas apa saja yang diberikan oleh guru mereka. Kebanyakan siswa tingkat SMP dan SMA tidak melaporkan adanya kelas-kelas kosong dimana guru mereka berhalangan hadir. Sehingga pembelajaran yang ideal di sekolah tidak terjadi dan menjadi tidak efektif.

Selain semua hal tersebut di atas ada beberapa hal lain perlu diperhatikan yaitu membantu anak mengenali dirinya (kekuatan dan kelemahannya), membantu anak mengembangkan potensi sesuai bakat dan minatnya, membantu meletakkan pondasi yang kokoh untuk keberhasilan hidup anak dan membantu anak merancang hidupnya.

\section{Hasil Belajar}

Belajar merupakan suatu proses usahan yang dilakukan seseorang untuk memperoleh suatu perubahan tingkah laku yang baru secara keseluruhan, sebagai hasil pengalamannya sendiri dalam interaksi dengan lingkungannya. Belajar juga dapat dikatakan bahwa serangkaian kegiatan jiwa raga untuk memperoleh suatu perubahan tingkah laku sebagai hasil dari pengalaman individu dalam interaksi dengan lingkungannya yang menyangkut kognitif, afektif, dan psikomotor.

Hasil belajar merupakan tujuan akhir dilaksanakannya kegiatan pembelajaran di sekolah. Hasil belajar dapat ditingkatkan melalui usaha sadar yang dilakukan secara sistematis mengarah kepada perubahan yang positif yang kemudian disebut dengan proses belajar (Dimyati, 2009: 3). Akhir dari proses belajar adalah perolehan suatu hasil belajar siswa. Hasil belajar siswa di kelas terkumpul dalam himpunan hasil belajar kelas. Semua hasil belajar tersebut merupakan hasil dari suatu interaksi tindak belajar dan tindak mengajar. Dari sisi guru, tindak mengajar di akhiri dengan proses evaluasi hasil belajar, sedangkan dari sisi siswa, hasil belajar merupakan berakhirnya penggal dan puncak proses belajar.

Menurut Sudjana, hasil belajar adalah kemampuan yang dimiliki siswa setelah menerima pengalaman belajar (Sudjana, 2010: 22). Selanjutnya Warsito mengemukakan bahwa hasil dari kegiatan belajar ditandai dengan adanya perubahan perilaku ke arah positif yang relatif permanen pada diri orang yang belajar (Depdiknas, 2006: 125). 
Seseorang dapat dikatakan telah berhasil dalam belajar jika ia mampu menunjukkan adanya perubahan dalam dirinya. Perubahan-perubahan tersebut di antaranya dari segi kemampuan berpikirnya, keterampilannya, atau sikapnya terhadap suatu objek.

Hasil belajar di sekolah merupakan salah satu ukuran terhadap penguasaan materi pelajaran yang disampaikan. Peran guru dalam menyampaikan materi pelajaran dapat mempengaruhi keberhasilan belajar siswa. Faktor-faktor yang mempengaruhi keberhasilan belajar siswa penting sekali untuk diketahui, artinya dalam rangka membantu siswa mencapai hasil belajar yang seoptimal mungkin.

\section{Metodologi Penelitian}

Penelitian ini merupakan penelitian kuantitatif, adapun metode dalam penelitian ini menggunakan metode survey, dengan lokasi penelitian adalah MIN se-Kota Palembang. Dalam penelitian ini peneliti akan menggunakan sampel pada siswa di MIN se-Kota Palembang. Ukuran sampel dihitung berdasarkan formulasi yang dikemukakan Isaac dan Michael.

Variabel dalam penelitian ini adalah kompetensi guru (X1), peran orang tua (X2), hasil belajar (Y). Teknik pengumpulan data akan dilakukan dengan wawancara, angket, observasi dan gabungan dari ketiganya. Teknik analisis data dalam penelitian ini menggunakan uji korelasi ganda (multiple Correlate). Uji korelasi ganda adalah suatu nilai yang memberikan kuatnya pengaruh atau hubungan dua variabel atau lebih secara bersama-sama dengan variabel lain. Selanjutnya untuk megetahui signifikansi korelasi ganda $X_{1}$ dan $X_{2}$ terhadap Y.

\section{Hasil dan Pembahasan}

Analisis dari data angket kompetensi guru pada MIN 1 Palembang didapatkan informasi bahwa nilai minimum yang dapat diperoleh dari pengisian angket yaitu dengan skor 39 dan nilai maksimum yang dapat diperoleh dari pengisian angket yaitu dengan skor 195. Maka dapat disimpulkan secara keseluruhan bahwa berdasarkan ratarata nilai angket maka rata-rata kompetensi guru di MIN 1 adalah 164.58 dengan kategori baik.

Selanjutnya analisis dari data angket peran orang tua pada MIN 1 Palembang didapatkan informasi bahwa nilai minimum yang dapat diperoleh dari pengisian angket yaitu dengan skor 20 dan nilai maksimum yang dapat diperoleh dari pengisian angket yaitu dengan skor 100. Maka dapat disimpulkan secara keseluruhan bahwa berdasarkan rata-rata nilai angket maka rata-rata peran orang tua di MIN 1 adalah 79.34 dengan kategori baik.

Selanjutnya analisis dari data angket kompetensi guru pada MIN 2 Palembang didapatkan informasi bahwa nilai minimum yang dapat diperoleh dari pengisian angket yaitu dengan skor 39 dan nilai maksimum yang dapat diperoleh dari pengisian angket yaitu dengan skor 195, maka dapat disimpulkan secara keseluruhan bahwa berdasarkan rata-rata nilai angket maka rata-rata kompetensi guru di MIN 2 adalah 169.7 dengan kategori sangat baik.

Analisis dari data angket peran orang tua pada MIN 2 Palembang didapatkan informasi bahwa nilai minimum yang dapat diperoleh dari pengisian angket yaitu dengan skor 20 dan nilai maksimum yang dapat diperoleh dari pengisian angket yaitu dengan skor 100, maka dapat disimpulkan secara keseluruhan bahwa berdasarkan ratarata nilai angket maka rata-rata peran orang tua di MIN 2 adalah 81.9 
Beberapa temuan selama penelitian diantaranya kebiasaan disiplin yang di terapkan di MIN 1 dan MIN 2 memberikan dampak kepada siswa, dimana siswa berangsur-angsur menjadi pribadi yang tertib, mempunyai karakter sopan santun yang baik, ramah kepada orang yang lebih tua ataupun dengan teman sebaya dan menjadi pribadi yang menghargai waktu. Bentuk disiplin yang paling nyata yaitu memberlakukan aturan tidak boleh datang terlambat baik siswa maupun guru yang mengajar di jam pertama. Sehingga kebiasaan disiplin tersebut menjadi karakteristik dari siswa dan guru di sekolah tersebut, kemudian peran orang tua juga memberikan peranan yang penting dalam memberikan dukungan untuk mewujudkan karakter disiplin.

Memberlakukan hafalan surat-surat pendek pada juz 30 disetiap jenjang/level kelas memberikan dampak terhadap adanya tanggung jawab dan target yang harus dicapai oleh siswa. Target-target yang harus dicapai itu memberikan nilai positif terhadap karaketristik siswa dimana siswa menjadi pribadi yang bertanggung jawab dan memiliki jiwa kompetitif untuk lebih unggul dan ada motivasi "harus bisa". Kondisi tersebut tentu berhubungan dengan peran orang tua untuk membimbing dan memandu siswa untuk menghafal surat-surat pendek pada juz 30.

Ada fakta bahwa sistem penerimaan siswa baru yang mampu menyaring caloncalon siswa yang memiliki kemampuan akademik yang tergolong baik dan sangat baik, sehingga siswa-siswa yang masuk di madrasah tersebut tergolong siswa-siswa pilihan. Rencana pelaksanaan pembelajaran yang disiapkan oleh guru terarsip dengan baik dan dalam perencanaan pembelajaran guru sudah mulai mengadopsi metode dan strategi mengajar yang cukup variatif. Dengan adanya dokumen yang terarsip tersebut memberikan gambaran bahwa unsure kompetensi guru sudah terwujud dan memberikan gambaran yang cukup baik. Proses pembelajaran didalam kelas yang sudah cukup variatif, guru sering menggunakan alat peraga dalam rangka membantu siswa untuk memahami materi atau alat peraga tersebut dijadikan ilustrasi untuk membangun konsep pemahaman siswa. Kondisi tersebut juga menggambarkan kompetensi guru dalam proses pembelajaran. Kondisi sekolah yang kondusif dan fasilitas yang cukup, lingkungan yang asri diciptakan dalam rangka menciptakan suasana akademik yang diharapakan memberikan dampak positif terhadap kegiatan belajar mengajar. Ada fakta bahwa sebagian besar orang tua menampakkan perannya dalam perkembangan sekolah siswa. Ada kepedulian orang tua terhadap kemajuan perkembangan kegiatan sekolah siswa. Bentuknya yaitu orang tua memantau pekerjaan rumah (PR) siswa, orang tua memantau hafalan surah-surah pendek, orang tua memantau perkembangan siswa disekolah, dikarenakan menurut informasi dari guru bahwa banyak sekali wali siswa yang berlatar belakang akademik yang cukup baik ada yang berpendidikan S-1 dan S-2 dan ada juga yang guru. sehingga kepedulian wali kepada siswa tentunya akan tampak.

\section{Uji Normalitas Data MIN 1 Palembang}

Uji normalitas data digunakan untuk melihat apakah data variabel $\mathrm{x}_{1}, \mathrm{x}_{2}$ dan variabel y termasuk dalam kategori data yang normal. Untuk itu peneliti menggunakan bantuan program Microsoft Office Excel, dimana tampilan hasilnya setelah dilakukan perhitungan dengan menggunakan Microsoft Office Excel yakni bahwa $\chi^{2}$ hitung $\leq$ $\chi^{2}$ tabel $(0.628 \leq 7.81)$, dengan demikian data $X_{1}$ berdistribusi normal. Data Peran orang tua siswa MIN 1 Palembang (Variabel $\left.\mathrm{X}_{2}\right)$, data bahwa $\chi^{2}$ hitung $\leq \chi^{2}$ tabel $(0.428 \leq$ 7.81), dengan demikian data $X_{2}$ berdistribusi normal. Maka dapat disimpulkan bahwa $\chi^{2}$ hitung $\leq \chi^{2}$ tabel $(2.868 \leq 7.81)$ dengan demikian data Y berdistribusi normal. Hasil uji 
validitas diatas menunjukan bahwa data yang diperoleh berdistribusi normal, maka bisa dilanjutkan dengan uji homogenitas data.

\section{Uji Homogenitas Data MIN 1 Palembang}

Uji Homogenitas data digunakan untuk melihat apakah data variable $\mathrm{X}_{1}, \mathrm{X}_{2}$, dan $Y$ termasuk dalam kategori homogen. Untuk itu peneliti menggunakan bantuan program Microsoft Office Excel, dimana tampilan hasilnya setelah dilakukan perhitungan dengan menggunakan Microsoft Office Excel sebagai berikut:

\section{Uji homogenitas}

Data Kelas Eksperimen

$\left(\mathrm{X}_{1}\right)$

\begin{tabular}{|l|l|}
\hline$x b a r=$ & 162.64 \\
\hline$s^{2=}$ & 61.74 \\
\hline$s=$ & 7.857481 \\
\hline
\end{tabular}

Data Kelas Pembanding $\left(\mathrm{X}_{2}\right)$

\begin{tabular}{|l|l|}
\hline xbar $=$ & 81.38 \\
\hline $\mathrm{s}^{2=}$ & 48.36 \\
\hline $\mathrm{s}=$ & 6.954135 \\
\hline
\end{tabular}

Data Kelas

Pembanding (Y)

\begin{tabular}{|l|l|}
\hline xbar $=$ & 79.66 \\
\hline $\mathrm{s}^{2=}$ & 32.64 \\
\hline $\mathrm{s}=$ & 5.713143 \\
\hline
\end{tabular}

dengan menggunakan rumus "=FINV $(0.05,24,24) "$ maka $\mathrm{F}$ tabel yaitu $=1.98376$

Dari perhitungan diatas terlihat bahwa $F_{\text {hit }}<F_{\text {tab }}$ Yaitu $1.8915<1.983$ itu artinya data tersebut homogen

Hasil uji diatas menunjukan bahwa data yang diperoleh homogen dan bisa bisa dilanjutkan dengan uji korelasi ganda

\section{Uji Korelasi Ganda Data MIN 1 Palembang}

Uji korelasi ganda digunakan untuk melihat apakah terdapat hubungan kompetensi guru dan peran orang tua terhadap hasil belajar. Untuk itu peneliti menggunakan bantuan program Microsoft Office Excel, dimana tampilan hasilnya setelah dilakukan perhitungan dengan menggunakan Microsoft Office Excel yakni

Kaidah pengujian signifikansi:

Jika $F_{\text {hitung }}>F_{\text {tabel }}$ maka signifikan

Jika $F_{\text {hitung }}<F_{\text {tabel }}$ maka tidak signifikan

Dari hasil perhitung diatas didapat $\mathrm{F}_{\text {hitung }}=3.933039$ dan $\mathrm{F}_{\text {tabel }}=3.443357$, maka $F_{\text {hitung }}>F_{\text {tabel }}$ yaitu $3.933039>3.443357$ dengan demikian maka, kesimpulannya yaitu terdapat hubungan yang signifikan antara kompetensi guru dan peran orang tua terhadap hasil belajar siswa MIN 1 Palembang

\section{Uji Korelasi Ganda Pada Data MIN 2 Palembang}

Uji normalitas selanjutnya adalah mengolah data yang didapat dari hasil penelitian lapangan di MIN 2 palembang. uji normalitas digunakan untuk melihat apakah data variabel $\mathrm{x}_{1}, \mathrm{x}_{2}$ dan variabel y termasuk dalam kategori data yang normal. Untuk itu peneliti menggunakan bantuan program Microsoft Office Excel, dimana tampilan hasilnya setelah dilakukan perhitungan dengan menggunakan Microsoft Office Excel sebagai berikut:

a. Data Kompetensi guru MIN 2 Palembang (variable $\mathrm{X}_{1}$ ) disimpulkan bahwa $\chi^{2}$ hitung $\leq \chi^{2}$ tabel $(1.401 \leq 7.81)$, dengan demikian data $\mathrm{X}_{1}$ berdistribusi normal

b. Data Peran orang tua siswa MIN 2 Palembang (Variabel $\mathrm{X}_{2}$ ) 
dapat disimpulkan bahwa $\chi^{2}$ hitung $\leq \chi^{2}$ tabel $(3.880 \leq 7.81)$ dengan demikian data $\mathrm{X}_{2}$ berdistribusi normal

c. Data Hasil Belajar (variable Y)

dapat disimpulkan bahwa $\chi^{2}$ hitung $\leq \chi^{2}$ tabel $(5.903 \leq 7.81)$ dengan demikian data $\mathrm{Y}$ berdistribusi normal

Hasil uji validitas diatas menunjukan bahwa data yang diperoleh berdistribusi normal, maka bisa dilanjutkan dengan uji homogenitas data.

\section{Uji Homogenitas Data MIN 2 Palembang}

Uji Homogenitas data digunakan untuk melihat apakah data variable $\mathrm{X}_{1}, \mathrm{X}_{2}$, dan Y termasuk dalam kategori homogen. Untuk itu peneliti menggunakan bantuan program Microsoft Office Excel, dimana tampilan hasilnya setelah dilakukan perhitungan dengan menggunakan Microsoft Office Excel sebagai berikut:

dengan menggunakan rumus "=FINV(0.05,24,24)"

maka $\mathrm{F}$ tabel yaitu

$$
=\quad \mathbf{1 . 9 8 3 7 6}
$$

Dari perhitungan diatas terlihat bahwa $\mathrm{F}_{\text {hit }}<\mathrm{F}_{\text {tab }}$ Yaitu $1.779<1.983$ itu artinya data tersebut homogen

Hasil uji diatas menunjukan bahwa data yang diperoleh homogen dan bisa dilanjutkan dengan uji korelasi ganda

\section{Uji Korelasi Ganda Data MIN 2 Palembang}

Uji korelasi ganda digunakan untuk melihat apakah terdapat hubungan kompetensi guru dan peran orang tua terhadap hasil belajar. Untuk itu peneliti menggunakan bantuan program Microsoft Office Excel, dimana tampilan hasilnya setelah dilakukan perhitungan dengan menggunakan Microsoft Office Excel sebagai berikut:

Kaidah pengujian signifikansi:

Jika $F_{\text {hitung }}>F_{\text {tabel }}$ maka signifikan

Jika $F_{\text {hitung }}<F_{\text {tabel }}$ maka tidak signifikan

Dari hasil perhitung diatas didapat $\mathrm{F}_{\text {hitung }}=3.933039$ dan $\mathrm{F}_{\text {tabel }}=3.443357$, maka $F_{\text {hitung }}>F_{\text {tabel }}$ yaitu $3.933039>3.443357$ dengan demikian maka, kesimpulannya yaitu terdapat hubungan yang signifikan antara kompetensi guru dan peran orang tua terhadap hasil belajar siswa MIN 2 Palembang.

\section{E. Kesimpulan dan saran}

\section{Kesimpulan}

Dari analisa pada bab IV dapat ditarik kesimpulan sebagai berikut:

a. Berdasarkan data yang didapatkan dari hasil penelitian terlihat bahwa rata-rata kompetensi guru di MIN 1 adalah 164.58 yang tergolong dalam kategori baik, kemudian rata-rata kompetensi guru di MIN 2 adalah 169.7 yang tergolong dalam kategori sangat baik.

b. Berdasarkan data yang didapatkan dari hasil penelitian terlihat bahwa rata-rata peran orang tua di MIN 1 adalah 79.34 yang tergolong kategori baik, kemudian rata-rata peran orang tua di MIN 2 adalah 81.9 yang tergolong dalam kategori baik 
c. Hasil perhitung didapat $\mathrm{F}_{\text {hitung }}=3.933039$ dan $\mathrm{F}_{\text {tabel }}=3.443357$, maka $F_{\text {hitung }}>F_{\text {tabel }}$ yaitu $3.933039>3.443357$ dengan demikian maka, kesimpulannya yaitu terdapat hubungan yang signifikan antara kompetensi guru dan peran orang tua terhadap hasil belajar siswa MIN 1 Palembang, kemudian Hasil perhitung didapat $\mathrm{F}_{\text {hitung }}=3.933039$ dan $\mathrm{F}_{\text {tabel }}=3.443357$, maka $F_{\text {hitung }}>F_{\text {tabel }}$ yaitu $3.933039>3.443357$ dengan demikian maka, kesimpulannya yaitu terdapat hubungan yang signifikan antara kompetensi guru dan peran orang tua terhadap hasil belajar siswa MIN 2 Palembang.

\section{Saran}

a. Perlu adanya pengawasan internal sehingga kompetensi guru dapat terpantau selama pelaksanaannya.

b. Pihak sekolah perlu memberikan pemahaman kepada orang tua siswa atau wali untuk mengambil peran dalam pengawasan siswa di lingkungan keluarga mulai dari kegiatan belajar di rumah maupun perkembangan pembelajaran di sekolah.

c. Bagi peneliti lain yang ingin melanjutkan penelitian ini disarankan betul-betul memetakan sampel penelitian sehingga subjek penelitian merupakan orang yang tepat dan mewakili kondisi sekolah tersebut.

\section{Daftar Pustaka}

Danim, Sudarwan. Profesionalisasi dan Etika Profesi Guru. Bandung: Alfabeta.

Depdiknas. (2006). Bunga Rampai Keberhasilan Guru dalam Pembelajaran (SMA, $S M K$, dan SLB). Jakarta: Depdiknas.

Dimyati dan Mudjiono. (2009). Belajar dan Pembelajaran. Jakarta: PT Rineka Cipta.

Keputusan Menteri Pendidikan Nasional No. 045/4/2002

Kunandar. (2011). Guru Profesional (Implementasi Kurikulum Tingkat Satuan Pendidikan dan Sukses dalam Sertifikasi Guru). Jakarta: Rajawali Pers.

Mulyasa. (2005). Menjadi Kepala Sekolah Profesional. Bandung: PT Remaja Rosdakarya.

Naim, Ngainun. Menjadi Guru Inspiratif. Yogyakarta: Pustaka Pelajar.

Sabri, Alisuf. (1998). Ilmu Pendidikan. Jakarta: Pedoman Ilmu Jaya.

Sholeh, A.N. (2006). Membangun Profesionalitas Guru. Jakarta: Elsas.

Sudjana, N. (2010). Penilaian Hasil Proses Belajar Mengajar. (Cet. XV). Bandung: PT. Ramaja Rosdakarya.

Sumiati \& Asra. (2007). Metodologi Pembelajaran. Bandung: CV. Wacana Prima.

Syah, Muhibin. (2000). Psikologi Pendidikan dengan Pendekatan Guru. Bandung: Remaja Rosdakarya.

Tim Penyusun Kamus Pusat Bahasa. (2002). Kamus Besar Bahasa Indonesia. Jakarta: Balai Pustaka.

Undang-Undang No.14 Tahun 2005 Tentang Guru dan Dosen

Usman, M.U. (2011). Menjadi Guru Profesional. Bandung: PT Remaja Rosdakarya.

Wahyudi, Iwah. (2012). Panduan Lengkap Uji Sertifikasi Guru. Jakarta: Prestasi Pustaka Raya.

Wibowo, M. E. (2001).Paradigma Bimbingan dan Konseling. Semarang: Depdiknas. 
JIP:Jurnal Ilmiah PGMI

Volume 4,No 1, Juni 2018
Hubungan Kompetensi guru .... Aquami \&tim

\section{Online:}

https://salwintt.wordpress.com/artikel/109-2/peranan-orangtua-sekolah-dan-gurudalammensukseskan-pendidikan, diakses tanggal 14 Juni 2017 